\title{
Biserica în societatea postmodernă. Misiune și mărturie ortodoxă în diaspora românească \\ Gheorghe VERZEA
}

Abstract: In the present document I have tried to outline the picture of the mission of our Church in western Europe starting from the two main coordinates: the time and the place we are living. The Church is asked to find solutions to the challenges of the present world. It is confronted with a multi religious reality, multi confessional, where the sects, in the context of the secularization introduce themselves as a valid religious alternative. Dealing with the orthodox parish orthodox life and the orthodox cult in the diaspora has as its main goal the seeding and the maintenance of the orthodox conscience through the pastoral care of the Church for its children and the activation of the communion of the Church.

Keywords: modernism, postmodernism, mission, diaspora, immigration, secular culture, pastoral care. 


\section{Introducere}

Studiul de față își propune o analiză a vieții creștine a ortodocşilor aflați în străinătate, plecând de la două realități precise și anume timpul în care trăim, adică epoca postmodernă, și locul vestul Europei. Nu putem să nu ținem cont de cele două coordonate, pentru că acestea influențează în mod firesc viața și, mai ales viitorul celor care trăiesc în aceste țări.

În prima parte a studiului vom prezenta câteva trăsături reprezentative ale timpului nostru, în ceea ce privește credința, marcând ceea ce oamenii de știință occidentali au considerat a fi emblematic pentru perioada pe care o analizăm. În a doua parte vom expune ceea ce Biserica noastră propune ca răspuns la provocările societăţii postmoderne occidentale.

\section{Modernitatea}

Pentru a vorbi despre epoca postmodernă trebuie să înțelegem mai întâi ce a însemnat modernitatea în istoria și cultura omenirii. Cele două cuvinte sunt etimologic și ideologic legate, iar conținutul lor trebuie analizat în secvență.

O posibilă definiție filozofică a modernismului ar putea fi: „Acel mod de a fi în lume, care, împreună cu lumea, este capabil să îşi dea şi condiţiile ei de posibilitate. Modernitatea este felul de a fi al omului care nu doar că respinge ideea însăşi de tradiţie - negând existenţa oricărei transcendențe -, nu doar că desființează orice raport cu transcendența, dar reuşeşte să modifice ad libitum condiţiile sociale de existenţă în genere".

\footnotetext{
${ }^{1}$ Pr. Lect. Univ. Dr. Ciocan Tudor Cosmin, Misiunea Bisericii în modernitate și postmodernitate, http://ctcresearch.ro/files/Download/CURS\%20DE\%20 misiologie\%208\%20 SUPLIMENT.2013.pdf (accesat 20.05.2015)
} 
Din punct de vedere istoric, modernitatea înseamnă dizolvarea și sfârșitul Evului Mediu și a culturii lui. $\mathrm{Cu}$ ea se intră într-o nouă etapă a istoriei, caracterizată de o nouă cultură, de o nouă concepție despre viaţă, de noi moduri de a gândi, de noi instituţii politice și sociale $^{2}$.

Actul artistic în modernitate înseamnă libertate. Libertatea modernă nu are definiție tocmai pentru că fiecare persoană tinde săși facă despre conținutul ideii de „modern” și a celei de „libertate modernă" o reprezentare particulară. Această particularitate pluralizează orice fenomen socio-cultural modern. Pluralitatea înseamnă totodată și subiectivism, independenţă, singularitate, mentalitate și gust interpretabile. Pluralismul duce la relativism, iar modern înseamnă tocmai „,o foarte accentuată relativitate”. Modernul reprezintă trecerea de la obiectivism şi unicitate la subiectivism şi pluralism ${ }^{3}$.

\subsection{Epoca modernă și credința creștină}

Din punct de vedere istoric și cultural, modernitatea se suprapune cu iluminismul. Această perioadă cunoaşte aspecte diferite de la o ţară la alta, de la o cultură la alta.

Astfel, în Franţa, iluminismul este marcat de opoziţia totală faţă de creştinism, în special faţă de Biserica Catolică. Această opoziţie a generat ateismul regimurilor de stat, creând un arc peste timp de 200 de ani, de la Revoluţia franceză până la cele din 1989, care au eliberat Europa de ideologia totalitară.

În Anglia iluminismul se caracterizează prin deism şi teologie naturală, iar în Germania este caracterizat de transformări interne ale

${ }^{2}$ Arhimandrit Teofil Tia, Elemente de „Pastorală Misionară” pentru o societate post-ideologică, Alba Iulia, Editura Reîntregirea, 2003, p. 27

${ }^{3}$ Adrian Marino, Modern, modernism, modernitate - Eseuri, București, Edit. Pentru Literatură Universală, 1969, p. 37, apud Pr. Lect. Univ. Dr. Ciocan Tudor Cosmin, Misiunea Bisericii în modernitate..., p. 236 
religiei şi teologiei într-un orizont protestant ce valorizează izvoarele religioase în plan cultural.

Perioada iluministă a marcat mai ales Bisericile occidentale, cu efecte, desigur, şi pentru popoarele ortodoxe ale Europei Orientale.

Timpul iluminismului s-a voit a fi unul al raţiunii, un timp pregătit de Renaştere şi, în parte, chiar de Reformă (care a distrus autoritatea eclezială în Occident), ce a contribuit la autonomia omului şi a raţiunii sale. Pentru noua paradigmă culturală, istorică, raţiunea umană devenea izvorul întregii cunoaşterii. Astfel, modernitatea exclude pe Dumnezeu din centrul existenţei propunând în locul viziunii teologice despre lume un antropocentrism radical al Creştinismului, Bisericii care a marcat modul de gândire şi e existenţa a omului în lume vreme de secole (secolele IV-XVIII), structurând Europa creştină, chiar dacă rămâne religia predominantă a vechiului continent, i se retrage teoretic supremaţia în domeniul cunoaşterii, al ştiinţei, pentru ca locul teologiei să fie redat ştiinţelor ${ }^{4}$.

Modernitatea radicalizează ruptura dintre credință şi raţiune începută de scolastica medievală şi, preluând elemente de ateism ale filosofiei populare, extins în anumite segmente nemulţumite de ingerinţa nemăsurată a Bisericii occidentale în viaţa privată a persoanei precum şi de libertinismul unor persoane eclesiastice sau politice, propune drept unic izvor al cunoașterii umane lumina naturală a rațiunii. Raţiunea umană nu se mai explică, astfel, prin Raţiunea divină, prin ordinea supranaturală; ci ea derivă din însăşi ordinea naturii, fiind independentă de normele şi postulatele tradiţiei, fie aceasta cea creştină.

${ }^{4}$ Pr. Lect. Univ. Dr. Ciocan Tudor Cosmin, Misiunea Bisericii..., p. 258 


\section{Postmodernitatea}

Lumea postmodernă pune credința într-o situaţie dificilă, iar dacă fiecare epocă a pus probleme specifice credinței, lumea de azi sfidează Biserica propunând societății modele contrare duhului creștin. Asistăm la o religiozitate generică, imprecisă care, de multe ori, cade în indiferență sau în sincretism. După căderea idolatriei rațiunii ${ }^{5}$, promovată de epoca modernă, omul postmodern caută noi forme de spiritualitate. A fost abandonate ,iluzille” epocii moderne, iar la nivel religios lumea se îndreaptă către o nouă viziune mistică a lumii ${ }^{6}$. Aceasta va conduce la o fragmentare a expresiilor religioase și la înmulțirea mișcărilor religioase alternative ${ }^{7}$.

Nietzsche este considerat „părinte al postmodernității”, el constată „moartea lui Dumnezeu”.

Nietzsche expune o pildă deosebită în acest sens, relatată în cadrul aforismului 125 din „Le gai savoir”. În aceasta relatare e vorba despre un „nebun” care aleargă disperat cu o făclie aprinsă în miezul zilei „prin mijlocul unui târg” strigând cu glas puternic „Unde este Dumnezeu?”, „L-a văzut cineva pe Dumnezeu?”, iar mulțimea mirată de gestul „nebunului” îi răspunde ironic și râzând: „Dumnezeu a murit!”, iar „nebunul” le oferă o replică pe măsură: „Dumnezeu nu a murit, noi l-am omorât!"

Prin această pildă Nietzsche exprimă nihilismul caracteristic vremii, modernismul pentru care Dumnezeu nu mai există, nu pentru că El nu a existat niciodată, ci pentru că El a fost omorât, haosul din sufletul omului reprezentând trecerea la o nouă eră: cea a

${ }^{5}$ Adică a certitudinilor absolute fundamentate pe rațiunea umană şi pe exercitarea raționalității științifice.

${ }^{6}$ Paolo Maino, Il postmoderno nella Chiesa? Il Rinnovamento Carismatico, Cinisello Balsamo, Edit. San Paolo, 2004, p. 44.

${ }^{7}$ A. N. Terrin, Risveglio religioso. Nuove forme dilaganti di religiosità. in „Credere oggi”, 11 (1991), p. 5.

${ }^{8}$ Pr. Lect. Univ. Dr. Ciocan Tudor Cosmin, Misiunea Bisericii..., p. 254 
postmodernismului, fatalitatea spirituală în care omul nu mai crede în metafizică, în adevăr, în idealuri și în valori. Același Nietzsche specifica în anul 1886: „Cel mai important din evenimentele recente este acela că «Dumnezeu a murit», credința în Dumnezeul creștin a devenit de necrezut, iar aceasta aruncă primele umbre asupra Europei"'.

Salvatore Natoli, în cartea sa, Dumnezeu și divinitatea. Confruntarea cu creștinismul, denumește noul curent pe care îl inaugurează Nietzsche, secularizarea secularizării.

„Dacă prima [cea care durează din Evul Mediu până în epoca modernă] a fost secularizarea mântuirii, cea contemporană [din epoca modernă și postmodernă] este secularizarea de mântuire. Prima a făcut transcendentul imanent, păstrând totuși modelul: de la mântuirea de timp la mântuirea în timp. Marele proiect al omului de a cuceri viitorul, omul în locul lui Dumnezeu. Secularizarea secularizării dizolvă însăși ideea de mântuire, înțeleasă ca mântuire necondiționată și absolută. Înseși proiectele umane dezvoltă în ele prea multe contradicții pentru a putea avea încredere în ele, cultivarea pretențiilor de omnipotență. Oamenii - am în vedere oamenii obişnuiți - azi, nu mai au nevoie de mântuire, eventual, îmbunătățirea propriilor condiții de viață"

În acest context, dupăArmando Matteo, se explică redescoperirea fascinația lumii grecești, a geniului păgânismului, a unei vieți pline de satisfacții pământești, imediate, marcate de duh dionisiac, a unui contact direct cu sacrul politeist, impersonal, anonim, apropiat de religia/înțelepciunea orientală: gândiți-vă la însuși Nietzsche, la Holderlin, la Hesse, la cea de-a doua speculație a lui Heidegger pe

\footnotetext{
${ }^{9}$ Armando Matteo, Il postmoderno spiegato ai parroci. Corso aggiornamento trepido clero 20-21 settembre 2004, p. 20, http://dimensionesperanza.it / aree/formazione-religiosa/teologia/item/6614-immaginare-dio-nella-postmo dernit $\%$ C3\%A0-armando-matteo.html (accesat 21.05.2015)

${ }^{10}$ Salvatore Natoli, Dumnezeu și divinitatea. Confruntarea cu creștinismul, Brescia, Morcelliana, 1999, p. 119
} 
tema sacrului ${ }^{11}$. De aici, discotecile și nebuniile de sâmbăta seara și grija minuțioasă față de propriul corp. Peste tot apar discoteci cu nume grecești (panta rei) sau centre de estetism numite Templul frumuseții. Toate acestea sunt expresii ale gândirii care a înflorit odată cu anunţul morții lui Dumnezeu și vor găsi ecouri în revoluţia socio-culturală din 1968 având ca idealuri visul democrației, eliberarea de tradiţii, libertate de expresie etc ${ }^{12}$.

\section{Religiozitatea în epoca postmodernă}

Una dintre trăsăturile cele mai surprinzătoare ale vremii noastre, dar care a început din ultimele două decenii ale secolului trecut, este trezirea religioasă, reîntoarcerea sacrului, și sunt persoane care vorbesc chiar de o ,religie postmodernă”.

Dar trebuie să subliniem faptul că nu este vorba de o întoarcere a religiei creștine, ci de forme religioase „,ără Dumnezeu”, în care dispare Dumnezeul personal pentru a face loc unui „divin” impersonal, înțeles ca energie cosmică, cu care omul și întreaga creație se poate unifica, desființând distincția dintre Dumnezeu și lume, între spirit și materie, într-o fuziune profundă și nedistinctă cu Divinul. Această unitate panteistă abolește toate contrastele și diviziunile, aducând „o pace și bucurie profundă, fruct al armoniei cu Natura și cu Totul"13.

Biserica este acuzată că se reduce la o formă exterioară ,învechită, rigidă și opresivă, care sufocă libertatea prin impunerea unor legi morale inumane, fiind lipsită în riturile de căldură umană și de forță emotivă și, de aceea, incapabilă să dea viață unei puternice și autentice experiențe a ,sacrului" ${ }^{14}$.

\footnotetext{
${ }^{11}$ Armando Matteo, Il postmoderno spiegato..., p. 22.

${ }^{12}$ Ibidem.

${ }^{13}$ Arhimandrit Teofil Tia, op. cit., p. 53.

${ }^{14}$ Ibidem, p. 54.
} 
Noile mișcări religioase sunt cele în cadrul cărora se exprimă în modul cel mai evident noua nevoie de sacru. Sociologul Zygmunt Bauman descrie această nevoie spunând că lumea caută în Dumnezeu un cirinean pentru crucea libertății lor. El spune:

„Bărbații și femeile postmoderni, că vor sau nu, sunt condamnați la o continuă alegere, iar arta de a alege se bazează în special pe a evita pericolul: acela de a nu lăsa să-i scape o bună ocazie, ori pentru că nu au văzut-o la timp, ori că nu s-au mobilizat destul pentru a o prinde, ori că le-a lipsit forța fizică sau spirituală de a o ajunge... Varianta postmodernă a incertitudinii nu generează nevoia de viziuni eshatologice în care este specializată religia, ci generează mai degrabă o cerere cât mai crescută de consultaţii esențiale date de experți în amorțirea sau tratarea identităţii. Bărbații și femeile postmoderni prinși în incertitudinea de tip postmodern nu vor predicatori care să-i mustre pentru slăbiciunile lor, pentru insuficiența rațiunii sau voinței lor. Caută în schimb niște consilieri capabili să-i convingă că lor nu le lipsește nimic din ceea ce trebuie unei vieți de succes și să le spună cum să-l găsească; să redea curaj celor pierduți, arătându-le că pentru orice defect există un remediu și că pacienții/clienții vor putea să realizeze tot ceea ce doresc, cu condiția să urmeze sfaturile lor și să le pună în practică, cu maximă seriozitate"'15.

În vremurile noastre există în lume peste 2200 mișcări religioase, în Italia sunt peste 600 , dintre care cei mai mulți sunt penticostalii protestanți, 400 milioane în lume și 300.000 în Italia ${ }^{16}$.

\footnotetext{
${ }^{15}$ Z. Bauman, Il disagio della postmodernità, Milano, Bruni Mondadori, 2002, p. 216.

${ }^{16}$ G. Angelini, La fede e la figura della coscienza, în M. Aletti, „La religione postmoderna. Atti del Convegno di studi svoltosi presso la Facoltà teologica dell'Italia settentrionale (Milano, 25-26 febbraio 2003)", Milano, Edit. Glossa, 2003, p. 194.
} 


\section{Misiune ortodoxă în diaspora românească}

\subsection{Condiția religioasă a emigrantului român}

Devenită un fenomen global, migraţia îi pune pe cei implicați, în faţa unor noi realităţi. Adaptarea la o societate cu alte valori şi priorităţi, integrarea şi împărtăşirea unui alt standard de viaţă, mai bun sau mai dificil decât cel din ţară, sunt tot atâtea probleme care îi privesc pe imigranţii români în Europa de Vest.

Vorbind despre românii care au plecat din țară de obârșie pentru a trăi în străinătate, putem spune că aceştia păstrează o legătură vie cu cei de un neam şi de o seminţie cu ei tocmai prin prezenţa la biserică și, uneori, prin descoperirea sau redescoperirea Bisericii în țările unde au ales să trăiască. Majoritatea dintre ei pleacă în străinătate pentru o viață mai bună şi, văzând că aceasta nu este de ajuns pentru a-i face fericiţi, s-au intors spre Dumnezeu, ca singurul şi adevăratul izvor al fericirii. Astfel, mulţi dintre ei au descoperit Biserica fiind în Occident, şi s-au adăugat comunităţilor deja existente. Alţi români au redescoperit Biserica pe care o cunoscuseră foarte puţin în România, iar un alt număr de români au continuat să fie prezenţi în Biserică, aşa cum fuseseră şi în România sau poate chiar mult mai prezenţi şi mai conştienţi de comoara găsită.

„Parohiile noastre - spune Preasfințitul Siluan al Italiei constituie punctul de referinţă pentru tot românul ortodox care doreşte să ducă o viaţă în continuitate cu valorile care îl definesc ca şi credinţă şi ca neam. Activitatea pastorală şi misionară a preotului din parohie este determinantă în ceea ce priveşte predarea şi cultivarea valorilor creştine care constituie factorul de coeziune în familia creştină atât de încercată" ${ }^{\prime \prime}$.

${ }^{17}$ Preasfințitul Siluan, Episcopul ortodox român al Italiei, Migrația intre regăsirea de sine și dorul de acasă, http://ziarullumina.ro/paradoxul-strainatatiiregasirea-interioara-88952.html (accesat 22.05.2015). 
Dar în Occident activitatea se desfăşoară într-o societate marcată de consum, care pune din ce în ce mai puţin accentul pe latura spirituală şi mai mult pe pragmatismul zilei. De aceea, grija pentru cele duhovnicești slăbește şi astfel, omul se găsește „dezbrăcat” de latura spirituală, care nu mai este practică şi utilă în societatea în care trăiește. De aceea, cei care vin din spaţiul balcanic ortodox, de multe ori, nu se mai regăsesc. Așa cum am mai spus, românii au luat drumul străinătăţii cu speranţa unui trai mai bun, dar în sufletul lor apar neliniştile, pe care, la început nu şi le explică. În multe cazuri, persoana se caută şi se regăseşte pe sine, atât spiritual, cât şi ca identitate etnică purtătoare de valori unice, pe care le descoperă şi le apreciază şi mai mult, atunci când trăiește în străinătate. În funcție de educaţia religioasă pe care a primit-o până la acea vârstă, emigrantul va ști să apeleze la Biserică și să se conecteze la valorile ce i-au fost predate sau, dimpotrivă, să-și găsească ,alinarea” în alte moduri, departe de Dumnezeu.

\subsection{Umbre care se abat asupra Bisericii din diaspora}

În ciuda străduinţelor și muncii episcopilor, preoților și credincioşilor ortodocşi români din Europa Occidentală și Meridională de a oferi creștinilor veniți la muncă, repere de viață și credință, rămân foarte multe întrebări la care încă nu putem răspunde.

Ce se va întâmpla cu cei $90 \%$ din creștinii noștri care nu frecventează Biserica? Spre deosebire de România, unde în fiecare localitate găsești biserici și preoți care să te îndrume, în străinătate, pentru a ajunge la biserică sau a întâlni părinți duhovnicești, îți trebuie un efort suplimentar. Iar acest efort se îngreuiază cu atât mai mult cu cât, de multe ori, nu există nici motivația interioară de a căuta cele ale lui Dumnezeu în pământ străin.

Una din preocupările administrațiilor locale din localităţile unde se află emigranți este aceea de a-i determina pe noii veniți să se 
integreze în „,țesutul social” al comunitătilor care îi primesc. În ceea ce-i privește pe tinerii români veniți în Italia, acest lucru nu ar trebui să le preocupe pe autorități. Se constată o putere deosebită a celor imigrați de a primi tot ce este nou, fapt care duce la o adaptabilitate rapidă.

Dacă această putere de adaptare este manifestată și în cele ce privesc religiozitatea, cei care nu au o educație solidă în cele ale Bisericii sunt dispuși să asimileze rapid ideile, atitudinile și comportamentul poporului care îi primește. Din analiza vremurilor în care trăim, făcută în prima parte a studiului nostru, rezultă că întreaga societate occidentală se află sub asaltul mentalității postmoderne. Concepțiile despre Dumnezeu și lume ale epocii postmoderne nu sunt deloc favorabile unei creșteri în credința ortodoxă. De aceea observăm dorința tinerilor de a se conforma obiceiurilor locale, cu o ușurință dezarmantă. Petrecerea nopților de sâmbătă în discotecă, în defavoarea participării a doua zi la Sfânta Liturghie; „frica” de a-și întemeia o familie și petrecerea a unor ani buni din viaţă în concubinaj; nepăsarea sau chiar ostilitatea față de Biserică și de cele sfinte, toate acestea se regăsesc în trăsăturile generale ale epocii postmoderne. La acestea se pot adăuga multe alte exemple, cum sunt grija exagerată față trup, de bunăstare, relativismul moral, cultivarea mândriei și a arivismului, egoismul etc. Cum vor putea fi recuperați acești tineri (și mai puțin tineri) pentru Biserică?

Dar cu copiii, ce se va întâmpla? Având în păstorire creștini tineri, Biserica noastră din Occident botează mulți copii. Acest lucru este îmbucurător, dar după botez, micul creștin trebuie și educat și hrănit cu Sfintele Taine, iar aceasta, cel puțin în primii ani depinde în mod exclusiv de părinți. Sunt multe motivele pe care părinții le invocă în apărarea lor atunci când sunt întrebați de ce nu aduc copiii mai des la biserică, iar unele dintre aceste motive sunt întemeiate. Totuşi, cel care pierde este cel nou-botezat. 
La vârsta școlară parohiile îi îndeamnă pe părinţi să-și aducă copiii la catehism, dar, din păcate, sunt puțini cei care răspund și își iau această responsabilitate în serios. Rămânem tot la maxim $10 \%$. Acestor întrebări le vor răspunde generațiile viitoare.

Una din grijile pe care preotul o are, este aceea de a ajunge la sufletul copilului născut în străinătate. Începând cu vârsta preșcolară copiii își însușesc limba țării în care s-au născut, atât de mult încât ei încep să gândească în această limbă. Este lăudabil efortul părinților de a-i învăța pe fiii lor limba română, și este firesc ca cei mici să o știe, dar nu trebuie uitat faptul că noi putem să pătrundem în mintea și sufletul lor dacă nu vorbim pe limba lor și la propriu și la figurat.

Trebuie anticipat viitorul. Două iniţiative voi cita în acest sens. Episcopia Italiei în curând va tipări traducerea unei cărți de rugăciuni în limba italiană, ceea ce va veni în întâmpinarea tuturor celor care gândesc și se exprimă mai bine în această limbă; iar cea de-a doua de referă la cult: introducerea de ectenii, lectura Sfintei Evanghelii, precum și a unor rugăciuni cum este „Tatăl nostru” în limba italiană, la Sfânta Liturghie. Sunt pași mici spre ceea ce se va desăvârși începând cu a doua generație de imigranți și anume introducerea în cult a limbii țării adoptive.

\section{Mărturisirea credinței ortodoxe în Occident}

În contextul misiunii Bisericii noastre în Occident este inevitabil contactul celelalte confesiuni creștine și chiar cu alte religii. În acest sens, credinţa ortodoxă se cere a fi mărturisită.

Adesea creștinii ortodocși sunt ,interogați” de către colegii lor de muncă, de către prieteni și cunoscuți, despre credința lor. Astfel, ei trebuie să explice de ce postesc, de ce în biserica lor slujbele durează atât de mult, de ce nu sărbătoresc Paștele împreună cu catolicii și altele. Fiecare va fi dat explicația în felul în care s-a priceput, uneori 
apelează și la ajutorul preoților pentru a lămuri anumite lucruri și a le explica apoi celor care i-au întrebat. Dar și ortodocșii învață multe lucruri de la colegii lor de serviciu catolici sau chiar musulmani. Are loc în acest fel un schimb de idei și impresii în cadrul căreia ortodoxia este mărturisită atât cu cuvântul, cât și cu fapta. Iar cele care mărturisesc cu fapta sunt în special femeile care lucrează în casele italiene și, de fiecare dată, trebuie să explice de ce țin post și se roagă.

Ecumenismul, termen tehnic și care pare prea pretențios pentru nivelul la care ne referim, pornește de la cunoașterea celuilalt, iar cunoașterea vine din prietenie și din descoperirea adevărurilor comune. Conviețuirea într-un teritoriu diferit din punct de vedere confesional conduce la această șansă, de a mărturisi altora credința în care te-ai născut.

La nivelul clericilor, Săptămâna de rugăciune pentru unitatea creștinilor este, cu siguranță, evenimentul cel mai vizibil pentru ceea ce se numește întâlnire interconfesională. Experiența anilor de slujire în Occident arată că nu trebuie lăsată inițitiva organizării întâlnirilor ecumenice exclusiv pe seama comunităților catolice, ci ortodocşii au dovedit cî pot fi ei înşiși protagoniști, gazde și promotori. Astfel, în parohiile ortodoxe, o seară din această săptămână este dedicată unei Vecernii în rit bizantin, celebrată și explicată în limba italiană.

În afara Săptămânii de rugăciune sunt multe iniţiativele prin care comunităţile ortodoxe din Vest propun manifestări religioase și culturale menite să dezvăluie bogăția credinței ortodoxe și tradițiile care derivă din ea. Ca exemple amintim: expoziţii de icoane și conferințe pe tema artei creștine ortodoxe; concerte de muzică religioasă, prilejuite de marile praznice ale creștinătății, Sf. Paști, Rusalii, Nașterea Domnului etc.; proiecție de film religios, cu dezbateri despre temele cuprinse în prezentare; preoții ortodocși sunt invitați în școli pentru a explica ortodoxia elevilor, iar bisericile noastre sunt gazde pentru elevii care doresc să viziteze un loc de cult ortodox.

Credința ortodoxă este mărturisită și la nivel înalt. Ierarhii și 
preoții sunt adesea invitaţi să expună conferințe și prelegeri în cadrul marilor simpozioane organizate la nivel naţional și chiar internaţional. Episcopia Italiei, la rândul ei, este promotoarea unui astfel simpozion numit „Colocviile Dionisiane”. Colocviile sunt organizate de Centrul de Studii Canonice și Patristice „Sfântul Dionisie Exiguul” al Episcopiei Ortodoxe Române a Italiei, în colaborare cu Universitatea „Magna Grecia” din Catanzaro (Italia) și cu Academia Română din Roma. Această manifestare se află deja la a cincea ediţie și invită personalități de diferite confesiuni pentru a trata teme religioase de înaltă ținută academică.

\section{Concluzii}

În lucrarea de față am încercat să creionăm un tablou al misiunii Bisericii Ortodoxe Române în Occident, plecând de la două coordonate precise: locul și timpul în care trăim. Biserica este cheamată să găsească soluții la provocările lumii contemporane, în faţa unei lumi pluri-religioase, pluri-confesionale, unde sectele, în contextul secularizării se recomandă drept o autentică alternativă religioasă. Asigurarea vieţii parohiale ortodoxe şi a cultului ortodox în diasporă are un scop concret: cultivarea şi menţinerea conştiinţei ortodoxe, prin grija pastorală a Bisericii faţă de fiii ei şi activarea sobornicității Bisericii.

Dincolo de diferențele confesionale, rămâne faptul că cei care aparțin Bisericilor „istorice” au același obiectiv actual: păstrarea creștinilor în duhul Tradiției sfinte, când noile mişcări religioase, apărute în climatul dezordonat postmodern vor să-i convingă pe cei botezați în numele lui Hristos că există o alternativă mai îmbietoare care se hrănește din hedonism și promovează relativismul ideologic, și să-i despartă de El, Lumina lumii, Calea, Adevărul și Viața. 